\title{
MELUMPUHKAN TINDAK PIDANA PENCUCIAN UANG DENGAN HUKUM PIDANA ISLAM
}

\author{
Ismail Marzuki ${ }^{1}$ \\ Email: ismail.mz2805@gmail.com
}

\begin{abstract}
Abstrak
Fenomena kejahatan pencucian uang (money laundering) akhir-akhir ini semakin banyak terjadi. Karena melalui saluran pencucian uang inilah, para pelaku kejahatan semakin eksis menjalankan berbagai aksi kejahatan. Hal ini dikarenakan materi atau harta hasil kejahatan mereka sebagai ruh yang menghidupi aksi perilaku jahat mereka dapat disembunyikan dengan rapi, serta dapat dimanfaatkan dengan baik karena tampak berasal dari sumber yang sah. Kondisi demikian jika dibiarkan, tentu banyak menimbulkan kerugian terhadap masyarakat. Apalagi jika kejahatan money laundering tersebut ditinjau secara filosofis dalam hukum islam (maqashid asysyari'ah). Mudharat yang ditimbulkan jelas lebih besar dari pada maslahahnya. Oleh karena itu, diperlukan strategi luar biasa untuk melumpuhkan atau memberantas perilaku tindak pidana pencucian uang tersebut.
\end{abstract}

\section{Kata Kunci: Pencucian Uang, Hukum Islam, Strategi Pemberantasan}

\begin{abstract}
The phenomenon of money laundering crime (money laundering) lately more andmore the case. Because through the channel of money laundering, the perpetrators increasingly exist run many actions a crime. This is due to the material or their proceeds of crime property as the spirit of the live action wicked behavior they can be hidden with a neat, and can be put to good use because it looked legitimate sourced. These conditions if left, certainly much cause any harm to society. Moreover, if such money laundering crimes reviewed philosophically in Islamic law (Sharia ash-trends). Regard posed obvious greater than maslahahnya. Therefore, the outstanding strategies needed to cripple or eradicate the behaviour a criminal offence of money laundering.
\end{abstract}

Keywords: Money Laundering, Islamic Law, Eradication Strategies

\section{PENDAHULUAN}

Pencucian uang (money laundering) merupakan salah satu upaya dari seseorang untuk menyembunyikan asal-usul hasil kejahatan yang telah dilakukannya. Jika dilihat dari asal katanya, pencucian uang berasal dari dua suku kata, yaitu cuci dan uang. Cuci bermakna membersihkan sesuatu yang kotor atau upaya untuk menghilangkan kotoran yang melekat pada sesuatu, dan uang adalah alat yang digunakan untuk menukar sesuatu dan diterima secara umum. Berdasarkan makna tersebut, muncul pertanyaan sederhana, mengapa uang perlu dicuci?

Untuk menjawab persoalan dimaksud, bukan berarti uang tersebut kotor secara fisik, yang perlu dicuci dengan air. Karena uang dalam hukum Islam tidak dapat

\footnotetext{
${ }^{1}$ Dosen Tetap di Fakultas Agama Islam, Universitas Nurul Jadid, Paiton Probolinggo.
} 
dihukumi dengan halal atau haram, yang dapat dihukumi demikian adalah perbuatan orangnya atau proses seseorang dalam memperoleh uang tersebut. Sehingga, frase pencucian uang lebih berorientasi pada makna bahwa uang yang diperoleh oleh seseorang itu merupakan hasil dari suatu kejahatan. Dalam kacamata jinayah, uang/harta itu diperoleh dari jalan yang batil/haram, misalnya didapat dari perbuatan mengambil/merampas harta yang bukan hak miliknya, narkotika, terorisme dan sebagainya. Atas dasar itulah, untuk menghilangkan jejak kejahatannya, seseorang itu kemudian mencuci "uang/harta haram" tersebut dengan berbagai cara di antaranya membuat usaha sendiri, berinvestasi, dan sebagainya, sehingga seolah-olah apa yang dihasilkan dari usaha atau investasinya itu merupakan hasil yang halal. Padahal Allah SWT telah berfirman:

$$
\text { يأيها الذين أمنوا لا تأكلوا أموالكم بينكم بالباطل }
$$

Artinya: "Hai orang-orang yang beriman!, janganlah kamu saling memakan harta sesamamu dengan jalan yang batil (tidak benar)".

Kalimat "laa ta'kuluu" dalam ayat di atas menurut pakar tafsir Indonesia Prof. Quraish Shihab tidak hanya bermakna "memakan" dengan arti memasukkan sesuatu ke mulut dan menelannya. Akan tetapi, maknanya juga berarti "cara memperoleh atau melakukan aktivitas". Dengan demikian, ayat di atas juga mengandung arti segala aktivitas atau kegiatan (termasuk pencucian uang) yang dilakukan oleh seseorang untuk mendapatkan harta secara batil, dihukumi haram.

Terlepas dari uraian di atas, akhir-akhir ini, strategi pencucian uang menjadi primadona para pelaku kejahatan, utamanya kejahatan dengan jenis white collarcrime. Hal ini tidak lepas karena dalam banyak hal, pembuktian kejahatan tindak pidana pencucian uang (TPPU) cukup pelik dan sulit. Ada banyak faktor penyebab peliknya pembuktian TPPU tersebut, di antaranya karena pelaku kejahatan selalu melibatkan banyak pihak, penyalahgunaan kecanggihan teknologi hingga penegakan hukum yang masih lemah.

Kendati aturan perundang-undangan mengenai TPPU telah ada dan diberlakukan di Indonesia, mulai dari UU No. 15 Tahun 2002 Tentang Tindak Pidana Pencucian Uang, jo. UU No. 25 Tahun 2003 Tentang Perubahan atas UU No. 15 Tahun 2002, hinggaUU No. 8 Tahun 2010 Tentang Pencegahan dan Pemberantasan Tindak Pidana Pencucian Uang, akan tetapi TPPU masih marak terjadi.

Berdasarkan uraian di atas, penulis tertarik untuk membahas lebih jauh mengenai TPPU dari sisi tinjauan hukum yang berbeda, bukan hukum positif, melainkan tinjauan hukum Islam, utamanya mengenai strategi hukum Islam dalam mengantisipasi dan memberantas tindak pidana pencucian uang.

\section{PEMBAHASAN}

\section{Hukum Islam dan Tindak Pidana Pencucian Uang}

Sebelum menguraikan masalah pencucian uang dalam hukum pidana Islam, perlu diketahui bahwa pencucian uang (money laundering) sebagaimana dituangkan dalam Pasal 1 UU No. 25 Tahun 2003 tentang Perubahan atas Undang-Undang Nomor 15 Tahun 2002 tentang Tindak Pidana Pencucian Uang adalah perbuatan

\footnotetext{
${ }^{2}$ QS. An-Nisa’ Ayat 29.
} 
menempatkan, mentransfer, membayarkan, membelanjakan, menghibahkan, menyumbangkan, menitipkan, membawa ke luar negeri, menukarkan, atau perbuatan lainnya atas harta kekayaan yang diketahuinya atau patut diduga merupakan hasil tindak pidana dengan maksud untuk menyembunyikannya, atau menyamarkan asalusul harta kekayaan sehingga seolah-olah menjadi harta kekayaan yang sah.

Ulasan singkat mengenai definisi money laundering menurut hukum positif di atas setidaknya dapat dijadikan acuan untuk membaca lebih jauh tentang tindak pidana pencucian uang dalam perspektif hukum pidana Islam. Berdasarkan paparan di atas juga, secara sederhana dapat dipahami bahwa money laundering adalah suatu perbuatan atau proses penyembunyian harta yang diperoleh dari hasil kejahatan, dengan tujuan menyamarkan asal-usul harta tersebut, sehingga seolah-olah menjadi harta yang sah.

Penyembunyian harta dengan menyamarkan asal-usul harta yang diperoleh dari hasil kejahatan tersebut dilakukan untuk menghindari law enforcement dari aparat penegak hukum. Oleh karenanya, pencucian uang masih sangat menjadi bisnis yang menarik di kalangan para pelaku white collar crime.

Kendati demikian, money laundering adalah perbuatan yang sangat merugikan masyarakat, bangsa dan negara. Salah seorang guru besar Universitas Diponegoro, Nyoman Serikat Putra Jaya mengatakan perbuatan pencucian uang di samping sangat merugikan masyarakat, juga dapat merusak stabilitas perekonomian nasional atau keuangan Negara dengan meningkatnya berbagai macam kejahatan. ${ }^{3}$ Satu hal yang perlu dikhawatirkan dari TPPU jika dibiarkan atau ada pembiaran, adalah munculnya berbagai macam bentuk kejahatan. Untuk itu peran penegak hukum dan masyarakat sangat dibutuhkan dalam mengungkap adanya TPPU dan menegakkan hukum kepada pelakunya, baik yang bersifat individu maupun institusi, seperti korporasi. Rasulullah SAW bersabda:

Artinya: "janganlah melakukan perbuatan yang membahayakan dirimu sendiri dan orang lain."

Selanjutnya, secara ekplisit, hukum pidana Islam (jinayah) tidak menyebut dengan tegas istilah pencucian uang. Ia hanya menyebut istilah-istilah yang memiliki kesamaan unsure dalam perbuatannya dengan istilah pencucian uang, di antaranya pencurian, penggelapan, penipuan, dan pengkhianatan. Secara umum, hukum Islam melarang segala bentuk perbuatan untuk memperoleh pendapatan atau harta (rizki) secara batil atau upaya untuk memiliki harta kekayaan secara tidak sah.

Pencucian uang diibaratkan dengan pencurian (sariqah) dalam hukum Islam, karena pelaku TPPU menyembunyikan harta yang diambilnya itu tanpa ada pemberian amanat atasnya. ${ }^{5}$ Pencucian uang diidentikkan dengan penggelapan

${ }^{3}$ Nyoman Serikat Putra Jaya, Sistem Peradilan Pidana (Criminal Justice System), Bahan Kuliah Program Magister Ilmu Hukum Universitas Diponegoro Semarang, hal. 114.

${ }^{4}$ Imam Yahya ibn Syarf Ad-Din An-Nawawi, Matan Al-Arba'in An-Nawawiyah, (Maktabah: Syaikh Salim Ibn Sa'ad Nabhani, t.t), hal. 37.

${ }^{5}$ Majelis Tarjih dan Tajdid PP Muhammadiyah, Tim Kerja Gerakan Nasional Pemberantasan Korupsi PBNU, dan Kemitraan bagi Pembaruan Tata Pemerintahan, Koruptor itu Kafir; Telaah Fiqih Korupsi Muhammadiyah dan NU, (Jakarta: PT. Mizan Publika, 2010), hal. 27. 
(ghulul) dalam hukum Islam, karena pelaku TPPU mengambil harta yang bukan haknya dan menyembunyikannya dalam hartanya. ${ }^{6}$ Pencucian uang disebut penipuan, karena di dalamnya mengandung unsur menipu aparat penegak hukum dengan menyembunyikan harta hasil kejahatannya, seolah-olah harta tersebut hasil dari aktivitas yang sah. Pun demikian dikatakan sebagai bentuk penghianatan, karena TPPU umumnya merupakan bentuk pengkhianatan atas amanah publik yang seharusnya dijalankan dengan baik.

Amanah yang telah diberikan masyarakat atau rakyat secara keseluruhan, seyogyanya tidak boleh disia-siakan, melainkan wajib ditunaikan dan diberikan kepada orang yang berhak menerimanya. Sehingga tidak boleh orang yang dibebankan amanah, mengingkari, menyembunyikan atau bahkan membelanjakan titipannya itu tanpa seizin pemilik hak yang sesuai dengan syari'at. Allah SWT berfirman:

إن الله يأمركم أن تؤدوا الامانات إلى أهلها

Artinya: "sesungguhnya Allah menyuruh kamu menyampaikan amanah kepada yang berhak menerimanya" ${ }^{7}$

Oleh karena hukum pidana Islam tidak secara eksplisit menyebut money laundering dalam nash, baik al-Qur'an maupun hadits, maka TPPU dapat dikategorikan sebagai jarimah ta'zir, yaitu suatu perbuatan pidana yang sanksi hukumannya ditentukan oleh Negara (pemerintahan yang sah). Al-Mawardi mendefinisikan ta'zir sebagai berikut:

$$
\text { والتعزير تأديب على ذنوب لم تثرع فيها الحدود }
$$

Artinya: Ta'zir adalah hukuman yang bersifat pendidikan atas perbuatan dosa yang hukumannya belum ditetapkan oleh syara'.

Berdasarkan definisi di atas, ta'zir merupakan istilah untuk hukuman (pidana), akan tetapi di kalangan ahli fiqih, makna ta'zir diperluas, tidak hanya mengacu pada hukuman, tetapi juga perbuatan pidananya. Sehingga jika dikatakan jarimah ta'zir itu berarti perbuatan pidana yang istilah dan hukumannya belum ditetapkan oleh syara'. Dengan kata lain, istilah ta'zir dalam hukum pidana Islam, dapat digunakan untuk istilah hukuman dan dapat pula untuk jarimah (tindak pidana). Di antara contoh jarimah ta'zir yang berkaitan dengan harta adalah memanipulasi harta anak yatim, menggelapkan harta waqaf, termasuk juga menggelapkan titipan ke dalam hartanya atau harta orang lain dengan tujuan untuk mengembangkannya, memperkaya diri, dan atau memilikinya.

Oleh karena money laundering belum ada ketetapan hukumnya dalam nash (diklasifikasikan sebagai jarimah ta'zir), maka landasan dan penentuan hukumnya didasarkan pada ijma' (konsensus/kesepakatan), dalam konteks Negara Indonesia berarti konsensus pemerintah untuk melakukan kriminalisasi dan menghukum semua

\footnotetext{
${ }^{6}$ Ibid., hal. 18-19.

${ }^{7}$ QS: An-Nisaa' ayat 58.

${ }^{8}$ Abu Al-Hasan Ali Al-Mawardi, Al-Ahkam As-Sulthaniyah, (Beirut: Dar Al-Fikr, 1966), hal.
} 236. 
perbuatan yang menyebabkan kerugian atau kerusakan fisik, sosial, politik, finansial, atau moral bagi individu atau masyarakat indonesia secara keseluruhan. ${ }^{9}$

Lebih jauh, dalam ajaran Islam ada beberapa kisah yang dapat dijadikan sebagai teladan bagi semua umat manusia, khususnya bagi umat Islam. Kisah pertama ialah tentang seorang laki-laki yang dalam sebuah perjalanan panjang, sehingga terlihat kusut dan kotor sekali rambutnya. Tiba-tiba ia menengadahkan tangannya ke langit seraya berkata "ya Rabb... ya Rabb..." padahal dibalik itu, ia senang makan makanan haram, minum dengan sesuatu yang haram, pakaiannya pun dari barang haram, dan kenyang dengan barang haram. Maka sabda Nabi SAW mengenai peristiwa tersebut, "bagaimana permohonannya dapat dikabulkan sementara ia senang dengan hal-hal yang haram?". 10

Peristiwa di atas mengajarkan kepada umat manusia bahwa benda haram yang menempel pada tubuh manusia dapat menjadi salah satu penghambat permohonannya dikabulkan. Hal ini selaras dengan sabda Nabi Muhammad SAW:

إن الله تعالى طيب لا يقبل إلا طيبا11

Artinya: "sesungguhnya Allah SWT maha baik, dan Dia tidak menerima kecuali sesuatu yang baik".

Pun demikian, perbuatan pencucian uang yang dilakukan oleh seseorang, bagaimanapun baiknya ibadah sosial yang ia lakukan, baik dengan bersedekah atau berinfaq dengan menggelontorkan sebagian uang/harta hasil kejahatannya kepada orang-orang yang membutuhkannya, nilai pahala dari perbuatan tersebut dihadapan Allah SWT nol besar atau tidak ada sama sekali. Bahkan, sekalipun yang ia sedekah atau infaqkan itu merupakan sesuatu yang paling ia cintai. Rasulullah SAW bersabda:

إذا تصدقت فتصدق بأحسن ما عندك فإن صدقة لقمة من الحلال احب إلى الله من مائة مثقال من حرامعaha 12

Artinya: "apabila engkau hendak bersedekah, maka bersedekahlah dengan sesuatu yang paling baik, yang engkau miliki. Sesungguhnya sedekah sesuap makanan yang halal lebih disukai Allah dari pada seratus mistqol makanan haram".

Teladan selanjutnya datang dari pasangan suami istri yang berkuasa pada masa kejayaan khalifah bani Umayyah, yaitu khalifah Umar ibn Abdul Aziz dan istrinya bernama Fathimah binti Abdul Malik, yang memiliki hadiah berupa perhiasan mewah dari sang ayah. Berikut percakapan di antara keduanya:

Pilihlah! Antara kau serahkan perhiasan itu ke baitul maal atau kau izinkan aku menceraikanmu. Karena sesungguhnya aku sangat benci jika aku, kamu dan perhiasan itu ada dalam satu rumah. Sang istri menjawab: "tidak, bahkan aku lebih memilihmu dari pada perhiasan itu sekalipun dilipatgandakan”. Lalu beliau memerintahkan istrinya menyerahkan perhiasan tersebut ke baitul maal. Ketika Umar ibn Abdul Aziz wafat, Yazid penggantinya berkata pada Fathimah (istri Umar ibn Abdul Aziz); “jika kau mau, aku bisa kembalikan perhiasan itu kepadamu”. Fathimah menjawab: “tidak, demi Allah!, ketika suamiku masih hidup, hatiku tidak tertarik

9 Topo Santoso, Membumikan Hukum Pidana Islam; Penegakan Syari'at dalam Wacana dan Agenda, (Jakarta: Gema Insani Press, 2003), hal. 23.

${ }^{10}$ Imam Yahya ibn Syarf Ad-Din An-Nawawi, Matan Al-Arba'in,. hal. 17.

${ }^{11}$ Ibid., hal. 17.

12 Tim Penerbit, Matan Washiyat Al-Musthafa lil Imam Ali Karramallahu Wajhahu, (Dar ArRahmah Al-Islamiyyah, tt), hal. 12. 
pada perhiasan itu, bagaimana mungkin sekarang aku menginginkannya setelah suamiku wafat". 13

Seorang pejabat tinggi Negara dengan status sebagai khalifah dan memiliki kekuasaan yang sangat besar, tentu jika menghendaki kekayaan yang melimpah, cukup hanya dengan satu tarikan nafas saja. Namun hal itu tidak dilakukan oleh khalifah Umar ibn Abdul Aziz. Jangankan mengambil kekayaan dari sumber-sumber Negara, hadiah dari orang tuanya yang begitu mewah pun beliau berikan ke baitul maal untuk kesejahteraan rakyat. Prinsip hidup sederhana dan lebih mementingkan kepentingan umum seyogyanya menghiasai setiap tindak-tanduk pejabat di Republik Indonesia ini. Hedonisme, konsumerisme dan fanatisme terhadap kelompok atau golongan yang dipelihara oleh sebagian besar pejabat di negeri ini hanya akan melahirkan trik-trik untuk memulai kejahatan-kejahatan baru, seperti money laundering.

Kisah atau teladan lainnya sebenarnya masih banyak, tetapi dari kedua peristiwa yang telah dideskripsikan di atas setidaknya kita sebagai rakyat Indonesia, lebih khusus lagi pejabat yang bergelut dengan berbagai macam persoalan bangsa, mulai dari masalah kejahatan ringan hingga kejahatan berat, baik yang bersifat nasional, transnasional maupun internasional, seperti korupsi, narkotika hingga money laundering, mampu bekerja dengan baik, dengan menempatkan kepentingan rakyat di atas kepentingan individu atau kelompoknya.

\section{Maqashid Asy-Syari'ah dan Tindak Pidana Pencucian Uang}

Istilah pencucian uang di Indonesia dapat dikategorikan sebagai jenis kejahatan baru. Perbuatan tersebut dikriminalisasikan dengan dikeluarkannya UU No. 15 Tahun 2002 tentang Tindak Pidana Pencucian Uang, setahun kemudian dirubah dengan terbitnya UU No. 25 Tahun 2003, hingga selanjutnya diganti dengan lahirnya UU No. 8 Tahun 2010 tentang Pencegahan dan Pemberantasan Tindak Pidana Pencucian Uang. Hal ini menunjukkan bahwa Indonesia semakin menyadari betapa bahayanya perbuatan pencucian uang (money laundering) bagi kehidupan berbangsa dan bernegara.

Diberlakukannya aturan hukum di atas tentu diharapkan dapat memberantas kejahatan money laundering, paling tidak mampu meminimalisirnya. Karena hakikatnya kejahatan tersebut sangat berpotensi mengancam stabilitas perekonomian suatu bangsa. Dengan lain perkataan, karena tindak pidana pencucian uang lebih banyak mafsadat (unsur kerugiannya) dari pada maslahahnya (unsur manfaatnya) bagi kehidupan bermasyarakat, berbangsa dan bernegara, maka perlu ada aturan hukum yang dapat mengatasi persoalan-persoalan hukum tentang money laundering tersebut.

Untuk mengetahui sejauhmana mafsadat yang diakibatkan dari kejahatan money laundering dalam hukum Islam, perlu dikaji dengan pisau analisa maqashid asy-syari'ah. Sebagaimana diketahui bahwa maqashid asy-syari'ah secara etimologi (bahasa) terdiri dari dua kata, yakni maqasid dan syari'ah. Maqashid, adalah bentuk

${ }^{13}$ Majelis Tarjih dan Tajdid PP Muhammadiyah, Tim Kerja Gerakan Nasional Pemberantasan Korupsi PBNU, dan Kemitraan bagi Pembaruan Tata Pemerintahan, Koruptor., hal. 149. Lihat juga dalam Al-Suyuti, Tarikh Al-Khulafa', hal. 232. 
jamak dari maqsủd, yang berarti "kesengajaan atau tujuan", sedangkan syari'ah, secara bahasa berarti "jalan menuju air/sumber kehidupan. ${ }^{14}$

Menurut Abdul Wahab Khallaf maksud umum disyari'atkannya hukum Islam (maqashid as-syari'ah) adalah untuk merealisir kemaslahatan umat dalam rangka memenuhi kebutuhan yang bersifat dharuriyat (primer), (yaitu menjaga agama, jiwa, akal, keturunan dan harta, pen.), hajjiyat (sekunder) dan tahsiniyat (tersier) ${ }^{15}$

Kelima kepentingan hukum yang wajib dilindungi di atas, yang disebut $\mathrm{Al}-$ Ghazali dengan istilah Kulliyat al-Khams, akan rusak jika seseorang melakukan kejahatan money laundering. Menjaga agama (hifd ad-din) sebagai prinsip pertama dalam teori maqashid asy-syari'ah dalam konteks sekarang tidak hanya mengacu pada persoalan keyakinan orang secara individual saja. Dengan kata lain, demi menjaga agama, maka setiap orang yang murtad (keluar dari agama Islam), halal darahnya. Tafsir teks dalam nash yang menyatakan bahwa kemurtadan menyebabkan halalnya darah seseorang perlu dikaji kembali, mengingat ajaran Islam, sesuai namanya adalah ajaran yang menyelamatkan seseorang dari kebinasaan. Di samping itu, nash-nash dalam hukum Islam yang menjunjung tinggi penghormatan terhadap hak-hak kemanusian sangat banyak dan lebih relevan untuk diterapkan di masa kini dan masa-masa mendatang.

Rusaknya agama (Islam) bukan karena banyaknya orang Islam yang memilih pindah kepada ajaran atau kepercayaan lain selain Islam, tetapi lebih kepada perilaku (akhlak) dari seorang muslim itu sendiri. Seorang muslim yang suka menutup-nutupi atau menyamarkan hasil kejahatannya, dan terbukti di sidang pengadilan sebagai pelaku kejahatan, akan menjauhkan rasa empati dan simpati orang lain terhadapnya. Perilaku seorang muslim yang terus-menerus mendhalimi orang lain, pada akhirnya akan mencoreng citra agama Islam itu sendiri, yang hakikatnya memiliki prinsip laa dharara wa laa dhirar (larangan untuk mendhalimi diri sendiri maupun orang lain).

Selanjutnya, menjaga jiwa (hifd an-nafs) sebagai prinsip kedua dalam teori maqashid asy-syari'ah menghendaki bahwa ajaran Islam sangat menghormati hak hidup seseorang. Makanya ada larangan untuk membunuh, melukai, dan menganiaya seseorang secara batil. Perbuatan pencucian uang sangat menganggu jiwa (an-nafs) seseorang yang seharusnya dijaga dan dihormati. Apalagi jika dilihat dari predicate crime dari kejahatan money laundering, seperti korupsi dan terorisme. Hasil kejahatan yang diperoleh dari kejahatan korupsi, kemudian ia samarkan dengan tujuan untuk menambah dan menumpuk harta kekayaan sebanyak-banyaknya demi memenuhi keinginan nafsunya, misalnya sebagian ia investasikan dalam bentuk property dan sebagian lainnya ia salurkan kepada orang lain untuk membuat teror, maka tidak akan terhitung berapa banyak jumlah korban/jiwa yang dirugikan akibat tipu muslihat dari pelaku pencucian uang tersebut.

Demikian pula, akal (al-'aql) sebagai salah satu bagian terpenting yang wajib dipelihara berdasarkan tujuan disyari'atkannya hukum dalam ajaran Islam. Posisi akal bagi kehidupan manusia sangat fundamental, karena tanpa akal, manusia hanyalah makhluk yang bersifat hewani. Dalam prinsip kehidupan kelompok hewani, siapa yang kuat, maka ia yang berkuasa. Hal ini tentu berbeda dengan kehidupan manusia,

\footnotetext{
${ }^{14}$ Ibn Manzur, Lisan al- 'arab, Juz VIII, (Bairut: Dar al-Sadr, t.th), hal. 175.

15 Abd Wahab Khallaf, Ilm Ushul al-Fiqh, (Kairo: Dar al-Qalam, 1990), hal. 198.
} 
yang penuh dengan kreativitas, keterampilan, dilingkupi berbagai bidang sosial, budaya, agama, pendidikan dan sebagainya. Di mana kesemuanya itu dijalankan semata-mata untuk mencapai kemaslahatan bagi kehidupan manusia, baik di dunia maupun di akhirat kelak. Proses untuk mencapai kemaslahatan tersebut tidak mungkin dapat dicapai tanpa salah satunya melibatkan peran akal di dalamnya.

Oleh karena itu, akal perlu dijaga dan dijamin keselamatannya dari kebinasaan. Salah satunya dengan cara menghentikan peredaran narkotika di negeri ini. Di samping itu, aparat penegak hukum wajib menelusuri, menumpas dan merampas hasil kejahatan dari pelaku kejahatan narkotika tersebut, agar terputus peredarannya. Karena dikhawatirkan harta hasil kejahatan narkotika itu disamarkan keberadaannya melalui financial system atau yang lainnya, dan digunakan kembali untuk menjalankan kegiatan haram tersebut.

Selanjutnya, amanah ketiga dari maqashid asy-syari'ah adalah menjaga keturunan (hifd an-nasl). Keturunan dalam ajaran Islam merupakan perihal yang diimpikan banyak pasangan suami-istri. Oleh karenanya, untuk mewujudkan maslahah yang berkaitan dengan keturunan, Islam mensyariatkan perkawinan dan untuk melestarikannya Islam melarang perzinahan, menuduh zina ( $q a d z a f$ ), abortus dan segala macam bentuk pencegahan kehamilan kecuali karena dharurat/hajat. ${ }^{16}$ Dari sini, kemudian muncul pertanyaan sederhana, mengapa zina, menuduh zina, abortus dan semacamnya itu dilarang dalam hukum Islam?. Hal ini tidak lepas karena adanya pengaruh yang sangat besar antara seorang perempuan dengan janin yang dikandungnya, bahkan pengaruh tersebut dapat terbawa hingga saat melahirkan. Rasulullah SAW bersabda:

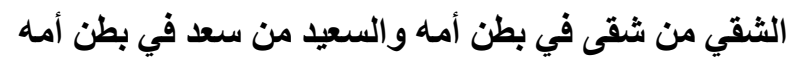

Artinya: "Yang sengsara adalah yang sengsara dalam perut ibunya dan yang berbahagia adalah yang berbahagia di dalam perut ibunya". ${ }^{17}$

Salah satu contoh yang dapat dikemukakan ialah apa yang disampaikan oleh Prof. Mansur Rajab dalam bukunya Ta'ammulat fi Falsafati al-Akhlaq. Beliau menceritakan kisah seorang wanita yang berhubungan seks tidak sah (berzina, pen) dengan dokter keluarga. Suatu ketika saat berhubungan itu sedang berlangsung, suami wanita tersebut datang, sehingga ia (wanita itu) diliputi oleh rasa takut yang mengakibatkan ia gemetar. Akhirnya ia melahirkan seorang anak yang cacat, serta gemetar seluruh tubuhnya. ${ }^{18}$

Oleh karena itu, para psikolog berkesimpulan bahwa apapun yang dirasakan oleh seorang wanita terhadap kehamilannya, apakah diliputi rasa takut atau optimisme, baik yang menyangkut janin atau dirinya, semua berpengaruh pada ibu dan janin saat kehamilan dan melahirkan. ${ }^{19}$ Dalam konteks globalisasi, persoalan perzinahan sangat erat kaitannya dengan pelaku pencucian uang. Karena salah satu kejahatan asal (predicate crime) dari kejahatan money laundering tersebut

16 Malthuf Siroj, Paradigma Ushul Fiqh; Negosiasi Konflik antara Mashlahah dan Nash, (Yogyakarta: Pustaka Ilmu, 2013), hal. 32.

17 M. Quraish Shihab, Pengantin Al-Qur'an; 8 Nasihat Perkawinan Untuk Anak-Anakku, (Tangerang: Lentera Hati, 2015), hal. 196.

18 Ibid., hal. 194.

${ }^{19}$ Ibid., hal. 195. 
sebagaimana dirumuskan dalam Pasal 2 ayat 1 huruf $\mathrm{u}$ adalah porstitusi. Dengan demikian dapat dipahami, bahwa harta kekayaan dari hasil tindak pidana porstitusi dapat pula dicuci dalam aktivitas-aktivitas yang terlihat halal, sehingga seolah-olah pelaku porstitusi mendapatkan harta kekayaan tersebut dari sumber yang sah. Untuk itu, diperlukan upaya-upaya yang mengarah pada pemberantasan tindak pidana pencucian uang (money laundering) tersebut, agar prinsip hifd an-nasl dapat terjamin keselamatannya.

Terakhir, hal yang juga sangat fundamental dalam maqashid asy-syari'ah adalah menjaga harta (hifd al-maal). Persoalan harta dalam kehidupan manusia dapat dikatakan sebagai persoalan yang pelik. Oleh karena di satu sisi, harta terkadang dapat membuat seseorang melakukan perbuatan-perbuatan tercela, seperti membunuh, korupsi, menjual narkotika, dan lain sebagainya. Sementara di sisi lain, harta dapat membuat seseorang untuk berbuat amal yang terpuji, seperti bersedekah, infaq, dan segala macam bentuk ibadah sosial lainnya.

Oleh karena itu, untuk menjaga kemaslahatan harta, Islam mensyari'atkan untuk melakukan berbagai macam transaksi (mu'amalah) yang halal dan berusaha mencari sumber penghidupan dengan cara yang baik. Islam sangat melarang bentukbentuk perampasan terhadap hak milik orang lain secara batil, seperti pencurian, perampokan, korupsi dan sebagainya, termasuk juga perbuatan pencucian uang.

Dengan demikian, menjadi jelas bahwa pelaku kejahatan money laundering telah melanggar kelima hal yang sangat prinsipil dalam hukum Islam. Maka terhadap pelaku tersebut dapat dikenakan sanksi sesuai dengan besar-kecilnya kerugian (mudharat) yang diakibatkan dari kejahatan yang ia lakukan.

\section{Faktor Penyebab Terjadinya Kejahatan Money Laundering}

Kejahatan money laundering dapat dikatakan sebagai kejahatan kedua, ketiga dan seterusnya (kejahatan lanjutan) dari kejahatan atau tindak pidana asal (predicate crime). Sebagaimana dirumuskan secara terperinci dalam Pasal 2 UU No. 8 Tahun 2010, bahwa tindak pidana asal dari perbuatan pencucian uang dapat berupa tindak pidana korupsi, penyuapan, narkotika, psikotropika, penyelundupan tenaga kerja, penyelundupan migran, di bidang perbankan, di bidang pasar modal, di bidang perasuransian, kepabeanan, cukai, perdagangan orang, perdagangan senjata gelap, terorisme, penculikan, pencurian, penggelapan, penipuan, dan sebagainya. Tindak pidana tersebut baik dilakukan di wilayah NKRI atau di luar wilayah NKRI dan tindak pidana tersebut merupakan tindak pidana menurut hukum Indonesia.

Berdasarkan uraian di atas, bahwa tindak pidana asal dari perbuatan pencucian uang tidak selalu berasal dari hasil kejahatan korupsi, tetapi dapat berasal dari hasil kejahatan-kejahatan lain seperti yang telah disebutkan di muka. Hal ini tentu semakin mempersulit proses penegakan hukum terhadap pelaku kejahatan money laundering. Maka perlu ada upaya untuk menguak sedini mungkin faktor-faktor penyebab seseorang melakukan perbuatan pencucian uang, khususnya menurut hukum pidana Islam.

Adapun faktor-faktor dimaksud, antara lain:

1. Globalisasi sistem keuangan. 
2. Adanya ketentuan bank di suatu Negara yang memperbolehkan penggunaan nama samaran atau nama yang tidak sebenarnya bagi nasabah.

3. Lemahnya pengawasan, baik di instansi pemerintahan maupun di dunia perbankan.

4. Banyaknya pilihan transaksi bagi nasabah di dunia perbankan, sehingga memudahkan pelaku kejahatan untuk menyembunyikan hasil kejahatannya. ${ }^{20}$

5. Penegakan hukum yang lemah.

6. Gaya hidup konsumerisme.

Selain beberapa faktor di atas, tentu masih banyak lagi faktor yang lain yang sulit diungkap, mengingat tindak pidana pencucian uang merupakan salah satu dari bentuk kejahatan yang cepat sekali perkembangan dan perubahannya.

\section{Strategi Pencegahan dan Pemberantasan Tindak Pidana Pencucian Uang Menurut Hukum Pidana Islam}

Dalam pandangan masyarakat modern, sanksi hukuman dalam hukum pidana islam masih dipandang sebagai suatu sanksi yang kejam dan sadis, utamanya yang berkaitan dengan kejahatan-kejahatan dalam kateogri had dan qishas. Dalam kasus pencurian misalnya yang secara dogmatis dalam al-Qur'an dikenakan sanksi potong tangan. Padahal dalam pelaksanaan hukum potong tangan tersebut, harus dipenuhi terlebih dahulu berbagai macam persyaratannya.

Demikian pula dalam perkara perzinahan, di mana pelakunya dapat dijatuhi hukuman had yang berat berupa hukum cambuk di hadapan publik. Mayortias masyarakat memandang bahwa hukuman tersebut sangat berat atau bahkan keras, padahal orientasi agama lebih kepada upaya untuk menjaga standar nilai-nilai moral. Tetapi orientasi agama yang demikian cenderung dianggap sebagai hal tabu di kalangan masyarakat modern, yang memandang perzinahan atau hubungan seksual di luar perkawinan tidak bertentangan dengan moral. ${ }^{21}$

Mengingat dua tindak pidana di atas adalah salah satu dari sekian banyak kejahatan asal (predicate crime) dari tindak pidana pencucian uang, maka perlu ada upaya-upaya atau strategi penanggulangannya, baik yang bersifat pencegahan (preventif) atau pemberantasannya (represif). Adapun beberapa strategi yang dapat dilakukan untuk mencegah terjadinya tindak pidana pencucian uang (money laundering) ialah sebagai berikut:

\section{Instrumen Pendidikan}

Dunia pendidikan sedikit banyak tercoreng reputasinya akibat perilaku pelaku kejahatan, khususnya pelaku pencucian uang, karena mayoritas yang melakukan kejahatan tersebut adalah mereka yang terdidik di dunia pendidikan. Masihkah ada harapan pada dunia pendidikan untuk menanamkan nilai-nilai anti pencucian uang? Apalagi di tengah-tengah masyarakat beredar sindiran "jangan sekolah tinggi-tinggi, nanti kerjanya korupsi”.

Betapapun, bahwa peran pendidikan untuk mencegah terjadinya berbagai bentuk kejahatan sangat penting, termasuk kejahatan money laundering. Karena

${ }^{20}$ Sam J.R. Saroinsong, Konsep Strategis Perbankan dalam Tindak Pidana Pencucian Uang, Vol.II/No.2//Januari-Maret/2014 Edisi Khusus, Jurnal Hukum UNSRAT, ISSN 1410-2358, hal. 53.

21 Topo Santoso, Membumikan., hal. 73-74. 
pendidikan seringkali disebut sebagai ruang terbaik untuk menyemaikan nilai-nilai moral dan pengetahuan sejak dini kepada penerus generasi bangsa.

Pendidikan seyogyanya tidak hanya diisi tentang bagaimana upaya melahirkan generasi yang memiliki keshalehan individual yang tinggi, tetapi lebih dari itu, pendidikan juga harus menuju pada upaya pencapaian membentuk peserta didik untuk memiliki jiwa keshalehan sosial yang besar. Karena setiap perilaku amoral, termasuk perbuatan pencucian uang terjadi akibat minimnya semangat keshalehan sosial yang dimiliki oleh jiwa seseorang.

Di samping itu, perlunya ada pengajaran atau pembelajaran tentang materi anti pencucian uang. Selama ini yang seringkali terdengar, baik dalam pelatihan, seminar, ataupun forum ilmiah lainnya, hanya persoalan-persoalan anti korupsi, anti narkotika, dan anti terorisme. Pengenalan terhadap ketiga tindak kejahatan tersebut baik, mengingat sebagian besar harta kekayaan yang disamarkan asalusulnya berasal dari berbagai jenis kejahatan yang tergolong kejahatan terorganisir ataupun white-collar crime seperti ketiga bentuk kejahatan di atas. Tetapi lebih baik lagi, jika di waktu yang sama, materi anti pencucian uang juga disemaikan dan ditanamkan kepada peserta didik. Tujuannya agar mereka juga mengetahui bahaya dari perbuatan pencucian uang yang sangat merugikan bangsa dan Negara.

\section{Instrumen Keagamaan}

Agama bagi sebagian besar orang diyakini sebagai petunjuk arah yang akan membawanya pada jalan keselamatan. Oleh karenanya, tidak ada agama apapun yang merestui perilaku-perilaku yang dapat mencederai kepentingan seseorang, baik secara individu maupun komunal/umum. Tetapi terjadi ironi dalam praktiknya, karena banyak para penganut agama justru melawan arus yang telah ditentukan dalam agama. Sehingga tidak sedikit di antara mereka dijatuhi hukuman atau sanksi akibat ulah perbuatannya itu.

Spirit agama secara normatif tetap dan tidak berubah, bahwa segala macam bentuk kedzaliman akan berakhir pada kehancuran. Perbuatan pencucian uang dapat dikatakan sebagai sebuah bentuk kedzaliman. Karena harta kekayaan yang dimiliki pelaku kejahatan pencucian uang diperoleh secara dzalim dan sebagian besar digunakan kembali untuk mendzalimi orang lain.

Lebih jauh, pesan-pesan agama tentang haramnya mengambil dan menggunakan hak milik orang lain secara tidak sah (ilegal) perlu terus-menerus digaungkan di berbagai kegiatan majelis keagamaan, baik di forum formal maupun non-formal. Harapannya melalui lembaga-lembaga keagamaan, praktik kejahatan pencucian uang dapat diminimalisir atau bahkan teratasi. Oleh karena itu, beberapa hal yang dapat dilakukan melalui jalur keagamaan ini antara lain adalah:

a. Mengoptimalkan potensi institusi-institusi ibadah, seperti masjid, sebagai tempat pembinaan umat.

b. Para tokoh agama (kiai, ulama', muballigh, dan sebagainya) hendaknya membekali dirinya dengan pengetahuan akan bahaya dari kejahatan extraodrinary crime, khususnya tindak pidana pencucian uang. Sehingga ketika menyampaikan ceramahnya di instansi-instansi pemerintahan atau di berbagai korporasi, tidak selalu diisi dengan ceramah agama semata, melainkan mampu 
mengkorelasikan sudut pandang agama tentang bahaya berbagai kejahatan extra-ordinary crime di atas, termasuk kejahatan money laundering.

c. Hal yang tidak kalah pentingnya adalah masyarakat wajib mendorong dikeluarkannya fatwa diharamkannya tindak pidana pencucian uang oleh para tokoh agama.

d. Tugas masyarakat dan para tokoh agama selanjutnya untuk mencegah tindak pidana pencucian uang adalah membersihkan lembaga-lembaga keagamaan, seperti masjid, madrasah, LAZIZ dan sebagainya, dari berbagai praktik pencucian uang. Dengan cara, selalu berhati-hati tatkala ada dana besar yang berkedok sedekah atau hibah dari donator.

\section{Instrumen Hukum dan Politik}

Hukum dan politik merupakan salah satu instrumen yang oleh sebagian kalangan dianggap sebagai cara yang cukup ampuh untuk mengamputasi tindak pidana pencucian uang. Namun ternyata dalam praktiknya, hukum dan politik seringkali digunakan untuk menggapai tujuan politik tertentu, baik yang bersifat individu maupun kelompok kepentingan tertentu. Sehingga tidak jarang ditemui di beberapa media massa sajian-sajian tentang tertangkapnya oknum penegak hukum, birokrat bahkan politisi, hingga putusan final terhadap mereka yang dilakukan oleh pihak yang berwenang di Negara ini.

Namun demikian, tanpa adanya sistem hukum dan politik yang terusmenerus dibangun menuju ke arah yang lebih baik, maka kehidupan bermasyarakat dan bernegara akan lebih sulit untuk bangkit dari keterpurukan. Terlebih jika sistem hukum dan politik dihadapkan dengan kejahatan yang memiliki karakter delik yang cepat berubah seperti tindak pidana pencucian uang. Oleh karena itu, ada beberapa strategi yang dapat digunakan untuk mencegah dan memberantas terjadinya tindak pidana pencucian uang, yaitu:

a. Membersihkan para penegak hukum, baik polisi, jaksa terlebih hakim, dari perilaku KKN. Hal ini dilakukan mulai dari proses seleksi yang harus transparan dan akuntabel. Para kandidat calon penegak hukum harus diseleksi dan dipilih secara benar, bukan didasarkan pada sikap nepotism, apalagi pada materi. Jika para calon penegak hukum dipilih dari generasi bangsa terbaik dan memiliki komitmen yang kuat untuk menegakkan hukum tanpa pandang bulu, maka tiap kejahatan, termasuk pelaku kejahatan pencucian uang, akan menerima sanksi yang sesuai dengan nilai-nilai keadilan masyarakat.

b. Mendorong pemerintah untuk membuat aturan perundang-undangan tindak pidana pencucian uang yang responsif terhadap perkembangan kejahatan pencucian uang. Di samping itu, pemerintah harus berupaya untuk memberi ruang pemahaman kepada rakyat akan bahaya kejahatan pencucian uang.

c. Mendorong masyarakat, baik LSM atau organisasi kemasyarakatan lainnya, untuk berani dalam membantu aparat penegak hukum dalam mengungkap terjadinya kejahatan money laundering. Di samping itu, berani pula dalam melakukan tekanan kepada pemerintah atau aparat penegak hukum untuk berani bertanggungjawab dalam menyelesaikan perkara tindak pidana pencucian uang.

d. Jajaran pimpinan, baik dalam lingkup partai politik maupun instansi pemerintah atau swasta, harus bersikap tegas dan tidak memihak jika ada kadernya yang 
terlibat kasus money laundering. Bersikap tegas tersebut juga berlaku terhadap dirinya sebagai pemimpin.

Beberapa instrumen di atas tentu masih sebagian hal yang dapat dilakukan untuk mencegah dan memberantas kejahatan money laundering. Jika mengacu pada pendapatnya G. Peter Hoefnagels, ketiga instrumen yang telah disebutkan dapat dikatakan sebagai upaya penanggulangan kejahatan melalui jalur nonpenal. ${ }^{22}$ Untuk itu, upaya pencegahan dan pemberantasan tindak pidana pencucian uang tidak cukup hanya dengan mengandalkan jalur non-penal, karena sesempurna apapun kebijakan yang dibuat oleh pemerintah maupun masyarakat dan para tokohnya, jika tidak dibarengi dengan penerapan hukum pidana (jalur penal), akan sangat sulit memberantasnya. Untuk itu ajaran islam dalam menyikapi pelaku kejahatan money laundering membolehkan pemerintah untuk menerapkan sanksi hukum yang bersifat penderitaan. Hal ini didasarkan pada pertimbangan hukum bahwa perbuatan pencucian uang sebagaimana uraian pada bagian sebelumnya dikategorikan sebagai jarimah ta'zir, karena telah memenuhi syarat-syarat perbuatan yang disebut sebagar jarimah ta'zir, yaitu:

a. Perbuatan tersebut tercela menurut ukuran moralitas agama, karena terkandung unsur merusak, merugikan dan membahayakan kehidupan manusia.

b. Perbuatan tersebut mencegah terwujudnya kemaslahatan bagi kehidupan manusia.

c. Adanya unsur merugikan kepentingan umum.

d. Perbuatan tersebut mengganggu kepentingan umum dan ketertiban umum.

e. Perbuatan tersebut merupakan bentuk maksiat yang dilarang.

f. Perbuatan tersebut mengganggu kehidupan dan harta orang lain, serta kedamaian dan kesejahteraan masyarakat. ${ }^{23}$

Untuk itu, ada beberapa sanksi pidana yang dapat diterapkan terhadap pelaku tindak pidana pencucian uang menurut hukum islam, antara lain:

a. Pengasingan; artinya pemerintah menyiapkan lokasi terpencil yang khusus dihuni oleh para pelaku kejahatan luar biasa (extra-ordinary crime), seperti korupsi dan money laundering dengan pengawasan (controlling) yang ketat. Di samping itu, dalam maknanya yang lebih luas, pengasingan harus melibatkan masyarakat. Dengan kata lain, masyarakat juga harus memberi sanksi moral kepada pelaku kejahatan money laundering, misalnya dengan tidak memberi posisi atau kedudukan penting di tengah-tengah masyarakat. Hukuman pengasingan ini pernah dicontohkan Nabi Muhammad SAW terhadap tiga sahabatnya, yaitu Ka'ab bin Malik, Murarah bin Rabi'ah Al-Amiri dan Hilal bin Umayyah Al-Waqifi, sebab enggan untuk ikut serta dalam sebuah

22 Nyoman Serikat Putra Jaya, Politik Kriminal, Bahan Kuliah Magister Ilmu Hukum Universitas Diponegoro. hal. 3.

23 Yusriana, Money Laundering dalam Pandangan Hukum Islam, hal. 9., digilib.mercubuana.ac.id/manager/t!@ file_artikel.../Isi_Artikel_113711974184.pdf., diunduh tanggal 03 September 2017. 
peperangan, dengan mendiamkan mereka, baik dalam pergaulan bahkan di pasar selama lima puluh hari. ${ }^{24}$

b. Penjara; merupakan sanksi atau jenis hukuman yang menekankan pada perampasan terhadap kemerdekaan seseorang, baik untuk sementara waktu maupun seumur hidup. Nabi Muhammad SAW pernah bersabda: "orang kaya yang mengulur waktu membayar hutang tanpa ada uzur adalah dzalim, maka halal harga dirinya dan hukumannya adalah penjara". ${ }^{25}$ Hadits tersebut mengizinkan pemerintah melalui aparat penegak hukumnya untuk memberi tindakan tegas kepada pelaku kejahatan, termasuk pelaku perbuatan pencucian uang berupa pidana penjara, terlebih jika ia tidak mau mengganti kerugian materil akibat dari perbuatannya.

c. Pemecatan; pelaku kejahatan money laundering umumnya adalah mereka yang memiliki kekuasaan dan jabatan tertentu. Sebagaimana diketahui, bahwa jabatan dalam ajaran islam bukan hak, melainkan sebuah amanat. Maka sudah sepatutnya amanah (jabatan) tersebut diberikan kepada orang yang dapat dipercaya, bukan kepada penghianat. Untuk itu, jika orang yang menduduki amanah tersebut berkhianat, maka harus diganti dengan orang-orang yang memiliki integritas dan kemampuan yang baik dalam jabatan dimaksud. Terlebih akan lebih baik, jika penghianat tersebut mengundurkan diri secara sukarela dari posisi jabatannya.

d. Hukuman mati; betapapun, hukuman atau pidana mati sangat diperlukan, kendati banyak para ahli hukum masih memperdebatkannya, terlebih jika dibenturkan pada persoalan HAM. Hukum islam pun sangat menghormati dan menjunjung tinggi HAM. Oleh karena itu, pemberlakuan pidana mati terhadap pelaku kejahatan harus berhati-hati dan diterapkan manakala kemashalatan menghendakinya, seperti kondisi pelaku yang tidak pernah jera dengan hukuman sebelumnya dan mengulangi kejahatannya, kejahatan tersebut marak terjadi di Negara yang bersangkutan. Untuk itu, jika kejahatan money laundering marak terjadi di negeri ini, maka tidak salah jika pemerintah mempertimbangkan pemberlakukan pidana mati.

Selain sanksi-sanksi yang telah penulis sebutkan di atas, jenis hukuman lainnya yang dapat diterapkan kepada pelaku kejahatan pencucian uang adalah denda dan penyitaan harta hasil dari kejahatannya. Dengan diketahuinya jenis sanksi ta'zir di atas, diharapkan pemerintah dan aparat penegak hukum menindak tegas dan adil terhadap pelaku kejahatan pencucian uang, mengingat dampak yang diwujudkannya sangat merugikan kepentingan dan ketertiban masyarakat.

\section{KESIMPULAN}

Berdasarkan uraian pada pembahasan di atas, tindak pidana pencucian uang (money laundering) merupakan jenis kejahatan yang tergolong extra-ordinary crime (kejahatan luar biasa) yang butuh penanganan yang luar biasa pula. Apapun modus

${ }^{24}$ Abi Zakariya Yahya bin Syarif An-Nawawi, Riyadlus Shalihin, (Surabaya: Nurul Huda, t.t), hal. 17-26.

${ }^{25}$ Majelis Tarjih dan Tajdid PP Muhammadiyah, Tim Kerja Gerakan Nasional Pemberantasan Korupsi PBNU, dan Kemitraan bagi Pembaruan Tata Pemerintahan, Koruptor, hal. 38. 
operandi yang dijalankan oleh pelaku kejahatan ini bertentangan dengan lima prinsip pokok dalam hukum islam yang wajib dipelihara dan dilindungi keberadaannya, yaitu menjaga agama, jiwa, akal, keturunan dan harta. Oleh karena itu, penjatuhan sanksi yang berat terhadap pelaku tindak pidana pencucian uang merupakan suatu keniscayaan.

Di samping itu, peran pemerintah, para tokoh, baik tokoh masyarakat maupun pemuka agama, dan masyarakat sangat penting dalam mengungkap praktik-praktik kejahatan money laundering. Lebih dari itu, peran mereka sangat dibutuhkan dalam upaya memberi pemahaman dan penyadaran akan bahaya dari tindak pidana pencucian uang yang sangat mengganggu upaya tercapainya kesejahteraan masyarakat.

\section{DAFTAR PUSTAKA}

Kitab Suci Al-Qur'an.

Nyoman Serikat Putra Jaya, Sistem Peradilan Pidana (Criminal Justice System), Bahan Kuliah Program Magister Ilmu Hukum Universitas Diponegoro Semarang.

Imam Yahya ibn Syarf Ad-Din An-Nawawi, Matan Al-Arba'in An-Nawawiyah, Maktabah: Syaikh Salim Ibn Sa'ad Nabhani, t.t.

Majelis Tarjih dan Tajdid PP Muhammadiyah, Tim Kerja Gerakan Nasional Pemberantasan Korupsi PBNU, dan Kemitraan bagi Pembaruan Tata Pemerintahan, Koruptor itu Kafir; Telaah Fiqih Korupsi Muhammadiyah dan NU, Jakarta: PT. Mizan Publika, 2010.

Abu Al-Hasan Ali Al-Mawardi, Al-Ahkam As-Sulthaniyah, Beirut: Dar Al-Fikr, 1966.

Topo Santoso, Membumikan Hukum Pidana Islam; Penegakan Syari'at dalam

Wacana dan Agenda, Jakarta: Gema Insani Press, 2003.

Tim Penerbit, Matan Washiyat Al-Musthafa lil Imam Ali Karramallahu Wajhahu, Dar Ar-Rahmah Al-Islamiyyah, tt.

Ibn Manzur, Lisan al- 'arab, Juz VIII, Bairut: Dar al-Sadr, t.t.

Abd Wahab Khallaf, Ilm Ushul al-Fiqh, Kairo: Dar al-Qalam, 1990.

Malthuf Siroj, Paradigma Ushul Fiqh; Negosiasi Konflik antara Mashlahah dan Nash, Yogyakarta: Pustaka Ilmu, 2013.

M. Quraish Shihab, Pengantin Al-Qur'an; 8 Nasihat Perkawinan Untuk AnakAnakku, Tangerang: Lentera Hati, 2015.

Sam J.R. Saroinsong, Konsep Strategis Perbankan dalam Tindak Pidana Pencucian Uang, Vol.II/No.2//Januari-Maret/2014 Edisi Khusus, Jurnal Hukum UNSRAT, ISSN 1410-2358.

Nyoman Serikat Putra Jaya, Politik Kriminal, Bahan Kuliah Magister Ilmu Hukum Universitas Diponegoro.

Yusriana, Money Laundering dalam Pandangan Hukum Islam, digilib.mercubuana.ac.id/manager/t! @file_artikel.../Isi_Artikel_113711974184. pdf., diunduh tanggal 03 September 2017.

Abi Zakariya Yahya bin Syarif An-Nawawi, Riyadlus Shalihin, Surabaya: Nurul Huda, t.t. 